Original Research Paper

\title{
Follicle Stimulating Hormone and Gonadotropin Releasing Hormone Administration to the Superovulation of Buffalo (Bubalus bubalis)
}

\author{
Tinda Afriani, Ferdinal Rahim, Arif Rachmat, Mangku Mundana and Anna Farhana \\ Department of Animal Science, Faculty of Agriculture, Andalas University, Padang, Indonesia
}

\author{
Article history \\ Received: 20-03-2020 \\ Revised: 14-04-2020 \\ Accepted: 29-04-2020 \\ Corresponding Author: \\ Tinda Afriani \\ Faculty of Animal Science, \\ Andalas University, Padang, \\ West Sumatra, Indonesia \\ Email: tindaafriani@ansci.unand.ac.id
}

\begin{abstract}
This study aims to determine the response of superovulation, corpus luteum number, onset and duration of estrus in Swamp Buffalo after administration of Follicle Stimulating Hormone (FSH) and Gonadotropin Releasing Hormone $(\mathrm{GnRH})$. The material used is 16 mother Swamp Buffaloes with an average body weight of $500 \mathrm{~kg}$ and age between 3-5 years. The dairy performance index such as the lactation period was $127.5 \pm 104.6$ days, the milk production accounted for $2.0 \pm 0.9 \mathrm{~kg} / \mathrm{cow} / \mathrm{day}$ and the milk yield was $255 \pm 209 \mathrm{~kg} / \mathrm{lactation}$. The experimental design used was a Completely Randomized Design (CRD) consisting of four replications. Swamp buffaloes are synchronized with $5 \mathrm{~mL}$ of PGF2 $\alpha$ injection. GnRH hormone injection on the 8th day at a dose of $500 \mu \mathrm{g}$ with 2 times in the morning and evening. FSH injection begins on the 10th day with 2 times a day i.e., morning and night ( $12 \mathrm{~h}$ interval) with a dose decreased for 3 days intramuscularly. Artificial insemination was carried out after signs appear estrus. The parameters observed include the superovulation response, the number of corpus luteum, the onset and duration of estrus in the Swamp Buffalo. The results obtained are the superovulation response in $56.25 \%$ Swamp Buffalo. The average number of corpus luteum, speed and duration of swamp buffalo estrus at different FSH doses and addition of $500 \mu \mathrm{g} \mathrm{GnRH}$ were $1.75,20.25$ and $145.75 \mathrm{~h}$ respectively. It was concluded that superovulation by administering a dose of $16 \mathrm{ml} \mathrm{FSH} \mathrm{+}$ $500 \mu \mathrm{g}$ GnRH has shown the best superovulation response and a long duration of estrus. The administration of $22 \mathrm{~mL} \mathrm{FSH}$ dose and the addition of $500 \mu \mathrm{g} \mathrm{GnRH}$ showed the fastest onset of estrus.
\end{abstract}

Keywords: Corpus Luteum, Superovulation Response, FSH $+\mathrm{GnRH}$ Hormone, Estrus, Swamp Buffalo

\section{Introduction}

Buffalo is one of Indonesia's local livestock species that can produce meat and milk. Buffalo is one of the local livestock that is mostly raised by farmers in West Sumatra, especially in Batang Anai District, Padang Pariaman District (Afriani, 2015). Buffalo population in Padang Pariaman Regency in 2016 was recorded at 13,925 individuals, which is a significant decrease compared to the 44,226 heads recorded in 2010 (BPS, 2016). The decline in the number of the buffalo cattle population is influenced by several factors such as poor buffalo reproduction management, frequent silent heat factors and the difficulty of estrus detection so that the implementation of artificial insemination is not appropriate (Ismaya, 2014). Productive buffalo production factors are in line with good reproductive performance (Chaiklun et al., 2012). Reproductive technologies applied in Indonesia are artificial insemination, embryo transfer, estrus synchronization and superovulation (Afriani et al., 2018).

Buffalos is a cattle that has an invisible cycle of estrus sometimes referred to as silent heat. This can be overcome by giving hormones that can stimulate the occurrence of estrus in buffalo cattle, so that the implementation of artificial insemination or embryo 
transfer can be done to increase the buffalo population in Indonesia, especially in West Sumatra (Putro and Kusumawati, 2014). Embryo transfer procedures that can be carried out like a superovulation program with GnRH injections that aim to stimulate the formation of many follicles and mature more quickly resulting in large ovulation, so that a large number of embryos will be obtained in one ovulation cycle (Feradis, 2010; Rahman et al., 2014).

Superovulation is the key to the success of TE, this can be determined by the high ovulation rate and the number of embryos obtained, while superovulation is also influenced by factors that influence the superovulation response in the donor parent, fertilization and viability of the embryo and factors related to donor parent management (Bearden et al., 2003; Situmorang et al., 2010). As stated at the outset of this research, this study aims to determine the response of superovulation, corpus luteum number, onset and duration of estrus in Swamp Buffalo after administration of Follicle Stimulating Hormone (FSH) and Gonadotropin Releasing Hormone (GnRH).

\section{Materials and Methods}

\section{a. Donor Selection}

Swamp buffaloes generally begin mating at an older age than river breeds. Young males are mainly first mated at about 3.0-3.5 years of age. Successful mating habits may go on until the animal is 12 years or even older (Ihsan, 2011).

\section{b. Superovulation}

Estrus synchronization in buffalo was injected with PGF $2 \alpha$ hormone as much as $5 \mathrm{~mL}$, GnRH hormone injection on the 8 th day with a dose of $500 \mu \mathrm{g}$ with 2 times in the morning and evening, FSH injection was started on the 10th day with 2 times daily i.e., morning and night days ( $12 \mathrm{~h}$ interval) with a dose decreased for 3 days intra-muscularly (Rahman et al., 2014). The hormone preparations used are FSH in 1 bottle of FSH (falltropin) containing $700 \mathrm{IU}=400 \mathrm{mg} / \mathrm{ml} \mathrm{NIH-FSH}-$ $\mathrm{P} 1$. All of the donor animals were administered $16 \mathrm{~mL}$ (320 mg), $18 \mathrm{~mL}$ (360 mg), $20 \mathrm{~mL}$ (400 mg) and $22 \mathrm{~mL}$ $440 \mathrm{mg})$. On the 11th day PGF2 $\alpha$ injection was administered at a dose of $5 \mathrm{~mL}$ intramuscularly.

\section{c. Artificial Insemination}

Artificial insemination was carried out for $12 \mathrm{~h}$ after the buffalo shows signs of estrus, in the form of symptoms and behavior of livestock. Estrus observation was carried out 3 times every day with a $12 \mathrm{~h}$ interval. Each donor was placed in a staple cage, artificial insemination was done by experienced inseminators (Geres et al., 2011; Miura et al., 2017).

\section{d. Research Parameters}

The parameters observed include the response rate of donor animals superovulated. Included in the parameters is the amount of Corpus Luteum (CL) after FSH administration with a dose of $16 \mathrm{~mL}(320 \mathrm{mg}), 18$ $\mathrm{mL}$ (360 mg), $20 \mathrm{~mL}$ (400 mg) and $22 \mathrm{~mL}$ (440 mg) and $500 \mu \mathrm{g}$ GnRH. Onset and duration of estrus in superovulated buffalo.

\section{e. Data Analysis}

The data obtained were processed statistically using analysis of variance. To determine the effect of intertreatment, further tests were performed. Further tests used were Duncan's Multiple Range Test (DMRT) according to Steel and Torrie (1995).

\section{Results and Discussion}

\section{a. Superovulation Response}

Superovulated donor buffalo with different FSH doses and the addition of $500 \mu \mathrm{g}$ GnRH obtained a total response rate of $56.25 \%$. Of the 16 buffaloes that were given superovulation treatment, 9 donor buffaloes responded positively and 7 donor buffaloes did not respond to superovulation treatment, as shown in the Table 1.

In Table 1 above, it can be seen that in the treatment of P1 with $16 \mathrm{~mL} \mathrm{FSH}$ and the addition of $500 \mu \mathrm{g}$ $\mathrm{GnRH}$, the best response rate obtained is $75 \%$ Because the higher the percentage of responses the better the response at the first treatment or in other words, the response is calculated by dividing the amount of CL by the number of buffalo injected with that dose. It is known that buffalo is a livestock whose lust is difficult to detect, so therefore, the response rate is also difficult to reach $100 \%$ as shown in Table 1 . The donor buffalo response obtained at a dose of $16 \mathrm{~mL}$ was lower compared to previous studies (Panjaitan, 2016) which obtained a $100 \%$ response rate in coastal cattle. Nanda (2012) reported that the use of $16 \mathrm{~mL}$ FSH dose obtained a response rate of $66.67 \%$. The success of the superovulation treatment can be seen from the ovarian response measured by the amount of CL formed due to ovulation from mature follicles (de Graff). The more CL formed can be said the higher the response from the superovulation program (Afriani et al., 2014).

Silva et al. (2009) argue that the factors that cause differences in the level of superovulation response are divided into 2 factors, namely internal and external factors. Internal factors include livestock genetics (breeds and individual sensitivity of livestock to 
hormones), nutrition and reproductive organ health. External factors include the use of FSH preparations, the dose of FSH used, the season and management of the implementation in the field. Different responses can be due to the physiological factors of each different animal.

\section{b. The Number of Corpus Luteum (CL)}

The amount of CL in buffaloes after FSH $+\mathrm{GnRH}$ superovulation can be seen in Table 2 .

Table 2, it can be seen that with the supplementation of various doses of the FSH hormone and the addition of $500 \mu \mathrm{g}$ of $\mathrm{GnRH}$, right ovaries are more numerous than left ovaries. This is in line with Haylan et al. (2009) who observe that right ovarian activity is more active at work than left ovary. Right ovary $(2.261 \pm 0.4552)$ is longer than left ovary $(2.239 \pm 0.4692)$. Right ovary $(1.561 \pm 0.3292)$ is wider than left ovary $(1.489 \pm 0.3989)$.

In Table 2. it is seen that the highest amount of CL is FSH $16 \mathrm{~mL}+500 \mu \mathrm{g} \mathrm{GnRH}$ (as much as $8 \mathrm{CL}$ ) followed by the FSH $18 \mathrm{~mL}+500 \mu \mathrm{g} \mathrm{GnRH}$ and FSH $22 \mathrm{~mL}+$ $500 \mu \mathrm{g} \mathrm{GnRH}$ (as much as $7 \mathrm{CL}$ ) while the lowest amount of CL is FSH $20 \mathrm{~mL}+500 \mu \mathrm{g} \mathrm{GnRH}$ (as much as $6 \mathrm{CL}$ ). Statistical tests show that the treatment is not significantly different ( $\mathrm{P}>0.05)$. Syaiful (2017) reports that the use of $14 \mathrm{~mL} \mathrm{FSH}+200 \mu \mathrm{g} \mathrm{GnRH}$ provides the best CL amount, which is $28 \mathrm{CL}$. The amount of $\mathrm{CL}$ superovulation in buffaloes can be seen in Table 3 .

Table 3 shows that the highest amount of CL at 16 $\mathrm{mL} \mathrm{FSH} \mathrm{dose}+500 \mu \mathrm{g} \mathrm{GnRH}$ (as much as $8 \mathrm{CL}$ ) followed by the acquisition of $\mathrm{CL}$ as much as $7 \mathrm{~mL}$ FSH supplementation $+500 \mu \mathrm{g}$ GnRH and FSH 22 $\mathrm{mL}+500 \mu \mathrm{g} \mathrm{GnRH}$ while the acquisition of $\mathrm{CL}$ as much as 7 in FSH supplementation $18 \mathrm{~mL}+500 \mu \mathrm{g}$ $\mathrm{GnRH}$ and FSH $22 \mathrm{~mL}+500 \mu \mathrm{g} \mathrm{GnRH}$ while the lowest acquisition of CL is FSH $20 \mathrm{~mL}+500 \mu \mathrm{g}$ GnRH (as much as $6 \mathrm{CL}$ ). Based on statistical tests showed that the treatment was not significantly different (P> 0.05). Syaiful (2017) reports that the use of $14 \mathrm{ml} \mathrm{FSH}+200 \mu \mathrm{g} \mathrm{GnRH}$ obtained the best CL amount, which is 28 CL. Nilchuen et al. (2011) reported the use of $200 \mathrm{mg}$ and $250 \mathrm{mg} \mathrm{FSH}$ concentrations in Saen and Heifers crossbred cattle showing a total CL of $8.67 \pm 0.98 ; 7.33 \pm 0.98 ; 10.33 \pm 0.98$ and 13.00 \pm 0.98 . Ali et al. (2012) reported that local Bangladeshi cattle injected $320 \mathrm{mg}$ FSH gave the best response to the amount of CL $13.60 \pm 0.51$ while the lowest mean CL amount was $8.60 \pm 0.60$ at $200 \mathrm{mg}$ FSH.

\section{c. Onset and Duration of Estrus}

The Following Fig. 1 shows the speed and duration of estrus in buffalo.

Table 1: The response of Buffalo Superovulation at Different Doses of FSH and the Addition of $500 \mu \mathrm{g} \mathrm{GnRH}$

\begin{tabular}{lllll}
\hline Treatment & Donor & Donor response & No response donor & Response rate $(\%)$ \\
\hline P1 $(16 \mathrm{~mL}+500 \mu \mathrm{g} \mathrm{GnRH})$ & 4 & 3 & 1 & 75 \\
P2 $(18 \mathrm{~mL}+500 \mu \mathrm{g} \mathrm{GnRH})$ & 4 & 2 & 2 & 50 \\
P3 $(20 \mathrm{~mL}+500 \mu \mathrm{g} \mathrm{GnRH})$ & 4 & 2 & 2 & 50 \\
P4 $(22 \mathrm{~mL}+500 \mu \mathrm{g} \mathrm{GnRH})$ & 4 & 2 & 3 & 50 \\
Total & 16 & 9 & 7 & 56,25 \\
\hline
\end{tabular}

Table 2: Total CL Superovulation of buffaloes at different doses of FSH and the addition of $500 \mu \mathrm{g}$ of GnRH to the right ovary and left ovary

\begin{tabular}{lc}
\hline & Corpus luteum number \\
Hormone treatment & Right ovaries \\
\hline $16 \mathrm{~mL} \mathrm{FSH}+500 \mu \mathrm{g} \mathrm{GnRH}$ & 6 \\
$18 \mathrm{~mL} \mathrm{FSH}+500 \mu \mathrm{g} \mathrm{GnRH}$ & 6 \\
$20 \mathrm{~mL} \mathrm{FSH}+500 \mu \mathrm{g} \mathrm{GnRH}$ & 4 \\
$22 \mathrm{~mL} \mathrm{FSH}+500 \mu \mathrm{g} \mathrm{GnRH}$ & 4 \\
Total & 20 \\
Rate & 5 \\
\hline
\end{tabular}

Table 3: CL amount of buffalo superovulation at different doses of FSH and addition of $500 \mu \mathrm{g} \mathrm{GnRH}$

\begin{tabular}{lccc}
\hline Treatment & Donor \# & CL \# & Average \\
\hline P1 $(16 \mathrm{~mL}+500 \mu \mathrm{g} \mathrm{GnRH})$ & 4 & 8,00 & 2,00 \\
P2 $(18 \mathrm{~mL}+500 \mu \mathrm{g} \mathrm{GnRH})$ & 4 & 7,00 & 1,75 \\
P3 $(20 \mathrm{~mL}+500 \mu \mathrm{g} \mathrm{GnRH})$ & 4 & 6,00 & 1,50 \\
P4 $(22 \mathrm{~mL}+500 \mu \mathrm{g} \mathrm{GnRH})$ & 4 & 7,00 & 1,75 \\
Total & 16 & 28 & 1,75 \\
\hline
\end{tabular}




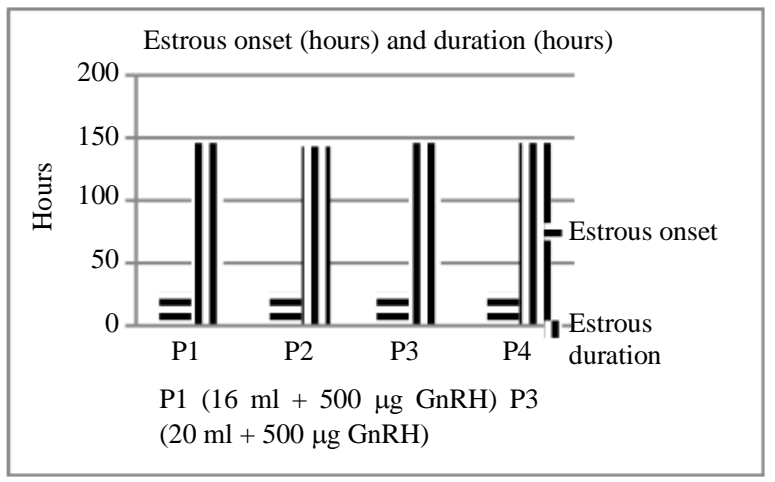

Fig. 1: Average estrous onset and duration in swamp buffalo with different doses

Based on Fig. 1, it can be seen that the Ovsynch superovulation treatment shows that the estrus rate is not significantly different $(\mathrm{P}>0.05)$. Based on the research conducted, the results obtained estrus velocity in buffaloes ranged from 25-26 h. Yendraliza et al. (2012) reported that the postpartum buffalo estrus velocity in Kampar District at the level of GnRH dose synchronized with $12.5 \mathrm{mg}$ of PGF $2 \alpha$ in a row in hours was $52 \pm 6 ; 53.88 \pm 5.1 ; 27.8 \pm 2.5 ; 28.8 \pm 0.5$ and $30 \pm 1.9$. Berber et al. (2002) who reported that the use of one dose of GnRH can improve the estrous cycle in buffalo and the use of two doses of GnRH will accelerate the emergence of estrus in buffalo when combined with PGF $2 \alpha$. In line with the report of Paul and Prakash (2005) who reported that the combination of the use of GnRH and PGF2 $\alpha$ would accelerate the emergence of estrus in buffalo.

Based on the results of the analysis of variance analysis. It was found that each treatment did not have a significant effect $(\mathrm{P}>0.05)$ on the duration of heat in superovulated buffaloes. The study found that the average duration of heat in buffalo is $145.75 \mathrm{~h}$. The duration of estrus depends on the number and quality of different follicles. Because a large number of follicles also correlates more and more with the estrogen produced also more, it is possible that the duration of estrus produced could be longer. Control of follicular growth waves is very important in the estrus superovulation and synchronization program, which affects the duration of the estrous cycle and the length of the luteal phase (Hafez, 2008).

\section{Conclusion}

From the research conducted, it can be concluded that the administration of $16 \mathrm{~mL}$ FSH dose and the addition of $500 \mu \mathrm{g} \mathrm{GnRH}$ has shown the best superovulation response and long lust. The administration of a $22 \mathrm{~mL}$ FSH dose and the addition of $500 \mu \mathrm{g} \mathrm{GnRH}$ showed the fastest heat rate.

\section{Acknowledgment}

The authors express their deepest gratitude to the Rector of Andalas University Padang, Indonesia and the Research Institute, LPPM, which funded this research through the Research Grant Number 96/UN.16,17/PP.PGB/LPPM/2018.

\section{Author's Contributions}

Tinda Afriyani and Ferdinal Rahim: Research conceptualization and design.

Tinda Afriyani, Arif Rachmat, Mangku Mundana and Anna Farhana: Data Collection and Interpretation.

Tinda Afriyani and Ferdinal Rahim: Writing and Editing.

\section{Ethics}

This research has been approved by the Committee of Ethics of the Faculty of Agriculture of Andalas University Padang, Indonesia and therefore, no ethical issues may arise after the publication of this research.

\section{References}

Afriani, T., Jaswandi, Defrinaldi and Y.E. Satria, 2014. Pengaruh waktu pemberian Gonadotropin Releasing Hormone (GnRH) terhadap jumlah korpus luteum dan kecepatan timbulnya berahi pada sapi pesisir. J. Peternakan Indonesia, 16: 193-197. DOI: 10.25077/jpi.16.3.193-197.2014

Afriani, T. 2015. Application of Reproductive Technology to Cows. Andalas University Press, Padang. pp. 12-44.

Afriani, T.; James, H.; Purwanti, E.; Ferdinal, R.; Arif, R.; Jaswandi and Mangku, M. 2018. Reproductive Technology in Buffalo. Andalas University Press, Padang. pp.8-16.

Ali, M.S., Khandoker, M.A. Afroz and A.K.F.H. Bhuiyan, 2012. Ovarian response to different dose levels of Follicle Stimulating Hormone (FSH) in different genotypes of Bangladeshi cattle. AsianAust. J. Anim. Sci., 25: 52-58.

DOI: 10.5713/ajas.2011.11167

BPS, 2016. Populasi ternak provinsi sumatera barat menurut kabupaten/Kota (Ekor), 2000-2016. Badan Pusat Statistik.

Bearden, H.J., J.W. Fuquy and S.T. Willard. 2004. Applied Animal Reproduction. 6th Edn., Prentice Hall, New Jersey, pp: 456.

Berber, D.R.C., F.H. Madureira and P.S. Baruselli, 2002. Comparison of two ovsynch protocols (GnRH versus $\mathrm{LH}$ ) for fixed timed insemination in buffalo (Bubalus bubalis). Theriogenology, 5: 8-17. 
Chaiklun, T., R. Hengtrakunsin and F.D. Rensis, 2012. Reproductive and dairy performances of Thai swamp buffaloes under intensive farm management. Thai J. Vet. Med., 42: 81-85.

Feradis, 2010. Bioteknologi Reproduksi pada Ternak. Penerbit Alfabeta Bandung. Anggota Ikatan Penerbit Indonesia. Bandung. Hal.

Geres, D., B. Zevrnja, D. Zubcic, R. Zobel and B. Vulic, 2011. Asymmetrical functional activities of ovaries and tubular part of reproductive organs of dairy cows. Reprotech, 81: 187-198.

Hafez, E.S.E., 2008. Preservation and Cryopreservation of Gamet and Embryos. In: Reproduction Farm Animals, Hafez, E.S.E. and B. Hafez (Eds.), Lippincott Williams and Wilkins, Maryland, USA, pp: 82-95.

Haylan, D., M.G. Angelica, A.C. Joel, R. Gle and Gentry, Jr. et al., 2009. Sex ratio of bovine embryos and calves originating from left and right ovaries. J. Biol. Reproduct., 81: 933-938.

Ihsan, M.N., 2011. Ilmu Reproduksi Ternak Dasar. 1st Edn., Universitas Brawijaya Press, ISBN-10: 6028960004, pp: 178.

Ismaya, 2014. Bioteknologi Inseminasi Buatan pada Sapi dan Kerbau. 1st Edn., Gadjah Mada University Press, Yogyakarta, ISBN-10: 979-420-848-5, pp: 117.

Miura, R., K. Yoshioka, T. Miyamoto, H. Nogami and H. Okada et al., 2017. Estrous detection by monitoring ventral tail base surface temperature using a wearable wireless sensor in cattle. J. Anim. Reprod. Sci., 180: 50-57.

DOI: 10.1016/j.anireprosci.2017.03.002

Nanda, M., 2012. Respon superovulasi sapi Pesisir dan sapi Simental. Tesis. Program Pascasarjana Universitas Andalas, Padang.

Nilchuen, P., S. Rattanatabtimtong and S. Chomcai, 2011. Superovulation with different doses of follicle stimulating hormone in Kamphaeng Saenbeef cattle. Songklanakarin J. Sci. Technol., 33: 679-683.
Panjaitan, R.Y., 2016. Respon superovulasi terhadap pemberian berbagai level Follicle Stimulating Hormone (FSH) pada sapi pesisir. Skripsi. Fakultas Peternakan Universitas Andalas, Padang.

Paul, V. and B.S. Prakash, 2005. Efficacy of the ovsynch protocol for synchronization of ovulation and fixed time artificial insemination in murrah buffaloes (Bubalus bubalis). Theriogenology, 64: 1049-1060.

Putro, P.P. and A. Kusumawati, 2014. Dinamika folikel ovulasi setelah sinkronisasi estrus dengan prostaglandin F2a pada sapi perah. J. Sain Veteriner.

Rahman, M.R., M.M. Rahman, W.E. Wan Khadijah and R.B. Abdullah, 2014. Comparison of superovulatory effect of equine chorionic gonadotrophin and follicle stimulating hormoneon embryo production in crossbred (Boer $\times$ Katjang) goats. Pak. J. Zool., 46: 819-826.

Silva, J.C.C., R.H. Alvarez, C.A. Zanenga and G.T. Pereira, 2009. Factors affecting embryoproduction in superovulated Nelore cattle. J. Anim. Reprod., 6: 440-445.

Situmorang, P., R. Sianturi, D.A. Kusumaningrum and E. Triwulaningsih, 2010. Pengaruhkonsentrasi Follicle Stimulating Hormone (FSH) terhadap tingkat ovulasi dan kelahiran kembar. JITV, 15: 278-285.

Steel, R.G.D. and J.H. Torrie, 1995. Prinsip dan Prosedur Statistik Suatu Pendekatan Biometrik. Edisi kedua. Alih Bahasa B. Sumantri. PT. Gramedia Utama, Jakarta

Syaiful, F.L., 2017. Suplementasi berbagai dosis hormon FSH dan GnRH terhadap perkembangan embrio sapi pesisir hasil superovulasi. Seminar Nasional Peternakan 3 Tahun 2017.

Yendraliza, B.P. Zespin, Z. Udin and Jaswandi, 2012. Penampilan reproduksi kerbau post partum pada berbagai level GnRHyang disinkronisasi dengan PGF2 $\alpha$. JITV, 17: 107-111. 